\title{
Infrastructural Facilities and the Practice of Vocational Business Education in Nigeria.
}

\author{
Egunjobi, John Olutope \\ Business Education Department, College Of Education, Ikere Ekiti
}

\begin{abstract}
Nigeria education system gives little or no attention to technology and vocational business education, an aspect of vocational and technical education (VTE) which was designed to prepare individual learner to earn a living and to be self reliant. The success of this aspect of educational policy is determined by its implementation which has been hindered by a lot of problems. This paper therefore examines the availability and utilization of infrastructural facilities in the implementation of vocational business education policy. Descriptive survey deign was used for the study. A sample of fifty lecturers was selected across the departments of Technical and Business in the College of Education, Ikere-Ekiti. A questionnaire tagged Infrastructural Facilities and Implementation of Business Education Questionnaire (IFIBEQ) was adopted. The findings revealed that, across the department there are not enough facilities, where available, they are not recent and many of the lecturers are not ICT compliant enough to handle the equipment. Based on the finding the researcher recommend among others, that the state government through the board for technical education, ministry of education and other government agencies should assist the colleges by making modern equipment available and organize training/workshps and seminars to globalize the lecturers by making them ICT compliant.
\end{abstract}

\section{Introduction}

The importance of infrastructural facilities in the implementation of any educational policy of a country cannot be overemphasized as human capital utilization can only succeed where appropriate facilities are readily available.

The practice of vocational business education today in Nigeria solely rely on the availability and applicability of infrastructural facilities hence the main focus of this paper is to examining the infrastructural facilities in the school system especially in Nigeria tertiary institutions and its influence on the implementation and practice of Vocational Business Education in our educational system in Nigeria.

Infrastructure is basically the physical and organizational structures needed for the operation of a society, system or enterprise, the service and facilities necessary for an economic to function (Aladejana, 2009). In the same vein Ajibola (2010) explained infrastructural facilities as the set of interconnected structural elements that provide development, hence, in the school system, infrastructural facilities are those equipment (Hard or Software) and materials other than human effort used in the teaching and learning processes.

Vocational and Technical Education (VTE) has been defined by many authors and organizations: The committee on Research and publication of American Vocational Association (1994) defined Vocational Education as "Education designed to develop skills, abilities, understanding, attitude, work habit, and appreciation, encouraging knowledge and information needed by workers to enter and make progress in employment on a useful and productive basis"

Nwokolo (1997) defined Vocational and Technical as instruments for attaining self-realization, individual and national economic efficiency, scientific and technological development.

Technical and Vocational education are extremely important in improving and progressing the nation's industries while supplying a capable workforce that can greatly reduce unemployment rates by giving people useful and money making skills. Business Education can improve efficiency in many industries and can lead to brilliant innovation in entrepreneurship such as renewable energy.

In President Obama's 2011 state of the union address, he emphasized the importance of improving the nation's education in Technical areas.

The central role of vocational business education in any country is to prepare it citizenry for work which can be achieved by impacting the right knowledge, skills attitude, and value with the appropriate availability of infrastructural facilities.

\section{Aims and Objectives of Vocational Business Education}

The general goals of Vocational and Technical Education under which Business Education reside as stated in the National Policy on Education (2004) are to: 
- Provide trained manpower in the applied science, technology and business particularly in craft, advance craft and technical cadre

- To provide technical knowledge and vocational skills necessary for agriculture, commerce and economic development.

- Give training and impact necessary skills to individual who shall be self-reliant economically.

However, to achieve these laudable objectives of the vocational business education, the infrastructural facilities needed must be super, sufficient, modern and appropriately provided to meet the yearning of $21^{\text {st }}$ century technological development.

The requirement by National Commission for Colleges of Education in Nigeria (NCCE) for the accreditation of courses in the department of Vocational Business Education includes the followings;

\section{Classrooms:}

Space that would take a minimum of thirty (30) students conveniently with sufficient passage within the classroom space should be made available for each lecture room while lecture halls of 1000 seating capacity could be made available.

\section{Laboratories/Studios:}

At least, one (1) each of typing-pool, shorthand laboratory, model office and information and communication technology (ICT) room must be available.

\section{Staff Offices:}

Each lecturer should be provided with a well-furnished office. The head of Department office should be provided with a computer and internet facilities. There should also be an office space for support staff (typists/computer operator, clerks, etc) with relevant equipment e.g computer, printer and reproduction machines (photocopier), etc.

\section{Book in the Library:}

A Departmental Library is compulsory, while there must be enough books to cover all the areas of the subject to the ratio of one student to ten books.

Equipment: Minimum required for a class of 30 students:

Equipment required for the teaching of the skills in the Business Education programme is as follows:

i. Equipment and supplies (for 30 students):

ii. Typewriters: (a). 30Manual Typewriters of various makes and types

2. Computers; The number should be in the ratio of one (1) computer to three (3) students.

3.. 30 Swivel typing chairs 4 . 30 Drop desk, Typist desk or convertible desks

5. (1) Instructor's Table or Desk $6 . \quad$ (1) Instructor's Chair

7. (4) Stapling machine $\quad 8$ (4) Staple removers

9. (3) Perforators $10 . \quad$ (3) Stop Watches

11. A Wall Clock $12 . \quad$ (1) Demonstration stand.

13. English/ Short hand dictionaries $14 . \quad$ (2) Filling Cabinets

ii. Shorthand Laboratory

1. Tape-recorders/ consoles 2. Headphones

3. Air-condition systems 4. Lecturer's demonstration stand

5. Punching machine 6. File cabinet

7. Appropriate furniture as technology may dictate from time to time.

8. Other electronic gadgets as technology may dictate from time ti time

\section{iii. Model Office}

1. Executive table with drawers and chair

2. secretary's table with drawers and swivel chair

3. Photocopier 4. File trays-in and out

5. Manual Typewriter and a computer 6. File cabinet

7. Adding and listing Machine 8. Waste paper basket.

9. Any other latest office equipment in the market.

iv. There should be an Information and Communication Technology (ICT) laboratory.

v. There should also be a well- equipped Entrepreneuralship centre 


\section{i. $\quad$ Statement Of The Problem}

There is the global awareness that one of the ways to economic sustainability of any country is the improvement in the entrepreneurship skill of the young undergraduates that makes them more employable and better still an employer of labour rather than depending on government/white collar job that is no longer readily available. In spite of this laudable awareness the researcher from experience observed that the infrastructural facilities to achieve this objective seems not available or not adequate where available, this necessitated this research to ascertain the extent of availability and its effect on achieving entrepreneurship skills in business education.

\section{Purpose of the Study}

The purpose of this paper is to examine the available of infrastructural facilities in our higher institution and its impact on the Vocational Business Education which is geared toward acquisition of salable skills for the younger generation in the society.

\section{Methodology}

The descriptive research design of the survey type was adopted for this study. The sample used consisted of fifty (50) lecturers in the school of Vocation and Technical education. The sampling techniques used for the study was simple random technique. Thirty (30) lecturers in the department of business education were selected while five lecturers each from other four departments were randomly selected to make up of the fifty (50) sample of the study. A self designed questionnaire was administered on the respondents. It was titled infrastructural facilities and implementation of Business Education Questionnaire (IFPBEQ). It was divided into two sections A\&B, section A contain information of the respondent bio- data while section B was 20 question items on the availability and usage of infrastructure in the school system. The reliability of the instrument was ensured. Reliability coefficient of 0.68 was obtained. This questionnaire was personally distributed to the selected members of staff as they were in close proximity to the researcher. The questionnaires were later collected after three days of distribution and analyzed using simple percentages.

\section{Research Questions.}

For the purpose of finding out the availability of Infrastructural facilities in the implementation of Business Education Policy, the following questions were generated.

1. Are there adequate lecture rooms/halls to cater for the population of students in the department of business education?

2. Are the staffs (academic and supportive staff) well accommodated?

3. Does the school have well equipped and maintained laboratories?

4. Is there a well- stocked departmental libraries in the school?

5. Is there any model office in the department with all other accessories?

6. Does the school have a well-established entrepreneurship unit?

\section{ii. Result And Discussion Of The Findings}

Research Question 1: $\quad$ Lecture halls/rooms

Table 1:summary of adequate o lecture halls/rooms for lectures.

\begin{tabular}{|l|l|l|l|l|}
\hline QUESTION & YES & NO & \%YES & \%NO \\
\hline 1 & 40 & 10 & 80 & 20 \\
\hline 2 & 20 & 30 & 40 & 60 \\
\hline
\end{tabular}

The questions which relate to availability of lecture halls/rooms, revealed that $60 \%$ of the responses were in negative. Though there were lecture theatre/halls and lecture rooms for lectures but they are not adequate considering the population of students in the department and the fact that other students from other schools/departments make use of these halls/rooms.

\section{Research question 2: $\quad$ Office accommodation}

Table 2: summary of availability of office accommodation for staff.

\begin{tabular}{|l|l|l|l|l|}
\hline QUESTION & YES & NO & \%YES & \%NO \\
\hline 3 & 15 & 35 & 30 & 70 \\
\hline 4 & 40 & 10 & 80 & 20 \\
\hline
\end{tabular}

$70 \%$ of the respondent to the question item shows that office space for lecturers are not enough except for few chief and principal lecturers, all other categories of lecturers share offices with each other because of lack of office accommodation. 
Infrastructural Facilities and the Practice of Vocational Business Education in Nigeria.

Research question 3: $\quad$ Laboratories

Table 3: summary of availability of laboratories

\begin{tabular}{|l|l|l|l|l|}
\hline QUESTION & YES & NO & \%YES & \%NO \\
\hline 5 & 50 & 0 & 100 & 0 \\
\hline 6 & 40 & 10 & 80 & 20 \\
\hline 11 & 40 & 10 & 80 & 20 \\
\hline 12 & 25 & 25 & 50 & 50 \\
\hline 13 & 10 & 40 & 20 & 80 \\
\hline
\end{tabular}

The finding reveal that there are laboratories in the department/school but that the laboratories lack necessary equipment, most especially the computer laboratories with a sitting capacity of 30 students has no functioning computer, no internet connectivity. The communication gadgets in the shorthand laboratory are in the state of disrepair while typewriters in the typing pool are not well maintained.

Research question 4: $\quad$ Library

Table 4: summary of availability and conduction of the departmental library.

\begin{tabular}{|l|l|l|l|l|}
\hline QUESTION & YES & NO & \%YES & \%NO \\
\hline 14 & 45 & 5 & 90 & 10 \\
\hline 15 & 22 & 28 & 44 & 56 \\
\hline
\end{tabular}

The result from the responses reveals that most departments has library and that the books there are absolutely insufficient.

Research question 5: $\quad$ Entrepreneurship centre

Table 5: summary of availability and state of entrepreneurship centre.

\begin{tabular}{|l|l|l|l|l|}
\hline QUESTION & YES & NO & \%YES & \%NO \\
\hline 16 & 0 & 50 & 0 & 100 \\
\hline 17 & 0 & 50 & 0 & 100 \\
\hline 18 & 0 & 50 & 0 & 100 \\
\hline
\end{tabular}

The responses of all the respondents representing 100\% showed that the college has no entrepreneurship centre.

Research question 6: $\quad$ Model office

Table 6: summary of the availability and situation of model office.

\begin{tabular}{|l|l|l|l|l|}
\hline QUESTION & YES & NO & \%YES & \%NO \\
\hline 19 & 0 & 50 & 100 & 0 \\
\hline 20 & 0 & 50 & 100 & 0 \\
\hline
\end{tabular}

The responses to the question show that the department has no model office which is one of major requirement for secretarial education department in the college.

\section{iii. Discussion}

The finding revealed that lecture rooms/halls, laboratories and other facilities are not sufficiently provided are not available and are not adequately furnished where available. This finding is against the submission of Aladejana (2009) who opined that infrastructure in basically the physical and organization structures needed for the operation of a society, system or enterprise, the service and facilities necessary for an economy to function. It was also discover that lecturers and support staff in the department have no befitting offices, meanwhile it is expected that, for optimum performance at work, a conducive environment is essential, this could be one of the reasons why staff appear not very is effective and the rate of labour turnover is high. Going by the result of the study it is obvious that what is operating in the school system is very far from the recommendation of NCCE facility minimum requirement. By implication the operational practice of business education cannot guarantee the realization of the objectives of business education as explain by Nwokolo (1997) that Vocational and Technical as instruments for attaining self-realization, individual and national economic efficiency, scientific and Technological development. Consequent upon the finding it therefore become necessary that effort should be geared up to ensure that both government, NGOS, school authority stepped up their efforts in meeting the required infrastructural facilities to boost business education that enhance selfreliance and entrepreneurship culture.

\section{iv. Conclusion}

Going by the finding of this study, it is evidenced that the condition of infrastructural facility in our institution is far below expectation of what is required to enable students acquire sufficient and robust learning skills and competencies that could make them self-sufficient, employable and entrepreneur oriented individual as amplified by the National Policy on Education. 
Equally, what is really on ground is far away from the minimum requirement of National Commission for colleges education (NCCE). No wonder that the department is sometimes denied full accreditation when the exercise come up in the institution.

\section{v. Recommendation}

As a result of the state of insufficient and inadequate infrastructural facilities in the institution, the following recommendations are made:

1. The state government should through the ministry of education, science and technology, formulate policies that would recognize the importance of infrastructural facilities in schools and executive such policies through prompt released of capital grant to schools and colleges for the provision of facilities that would enhance the acquisition of employable and salable skills is schools.

2. The federal government through its agencies such as Tetfund, National Communication Commission (NCC) and others, intensify effort at increasing their intervention agenda in tertiary institutions in the country so as to provide more facilities. Such fund when released must equally be monitored to see that such fund is judiciously utilized. The federal government through Tetfund should specially fund the construction of a modern Model offices and befiting entrepreneurship centres in all the colleges of education now that government is laying emphasis on entrepreneurship education in tertiary institutions.

3. The management of colleges of education should complement the efforts of both state and federal government by looking inward through their (IGR), Internally General Revenue to provide necessary facilities that would enable their institution excel in vocational training.

4. The institution could also collaborate with NGO's, donor agencies, and other relevant bodies for grants and aids that could be used to procure equipment for the colleges.

5. The institution should also collaborate with the (NDE), National Directorate of Employment for mutually beneficial programmes.

6. Regular seminars and workshops should be organized locally to make every academic staff of Business department ICT compliance while the college should encourage staff to attend international conferences to updated their knowledge and be abreast of current happenings and challenges in business education.

\section{References}

[1]. Ajibola (2010). Teacher production: A focus on Nigeria. In the state of Education in Nigeria, Abuja, UNESCO

[2]. Aladejana (2009). School effectiveness: criteria and evidence. The Scottish Council for research in education.

[3]. Alon, llan and John R (2004). Business Education and Emerging Market Economics.

[4]. Bayajide (2011). Journal of Education, College of education academic staff (COEASU) Federal College of Education Kastina chapter.

[5]. Egunjobi J.O (2008). Introduce to Methodology in Business Education. .Bamigboye Press. Ado Ekiti. Nigeria

[6]. Ehiamatalor E.I (1988). Business and Economics; Theory and methods

[7]. Federal Republic of Nigeria (2004). National Policy on Education.

[8]. National commission for College of Education (2004) Minimum Standard. 